\title{
Legal Protection for Hospitals in Providing Health Services for Patients and Their Family
}

\author{
Wafda Vivid Izziyana ${ }^{*}$, Andhika Yuli Rimbawan ${ }^{2}$, Martha Eri Safira ${ }^{3}$,
}

\author{
Arief Budiono ${ }^{1}$, Dewi Iriana ${ }^{3}$
}

\author{
${ }^{1}$ Universitas Muhammadiyah Ponorogo, Ponorogo, Indonesia \\ ${ }^{2}$ Patria Artha University, Gowa, Indonesia \\ ${ }^{3}$ IAIN Ponorogo, Ponorogo, Indonesia \\ *Corresponding author. Email: wafda.vivid@yahoo.com
}

\begin{abstract}
According to the Constitution No. 44 of 2009 concerning Hospitals, it is explained that a hospital is a health service institution for the people with its own characteristics which is influenced by health science development, technology advancement and the people's socio-economic life which must be able to improve the better-quality services and be affordable for the people in order to achieve the highest degree of health. From this definition, it can be seen that hospitals are very much needed to provide the best health service for the people. However, it is not uncommon that hospitals and its internal instruments, such as the medical staff and the allied health staff, nursing staff, pharmaceutical staff, management staff, and administrative staff experience verbal or nonverbal abuse both from patients or their families, not to mention that it happens if there are cases of medical malpractice. The purpose of this study is to observe the extent of the Constitution No. 44 of 2009 concerning Hospitals has been well implemented by the Hospital to improve its services for patients and their families. This study is an exploratory-descriptive study with a statutory approach. The existence of the Law No. 44 of 2009, apparently has not been able yet to provide strong legal protection for Hospitals in the cases relating to patients and their families. It needs revision on several Articles in Law, to be able to provide fair and balanced legal protection, especially for the Hospitals, because if there is a case against patient or patient's family, the community tends to judge that the Hospital is guilty or has committed medical malpractice. The reverse-charging principle of criminal law should also be applied in the Constitution No. 44 of 2009.
\end{abstract}

Keywords: legal protection, hospital, health services

\section{INTRODUCTION}

Cases between patients and hospitals and health workers (doctors, midwives, nurses) have increased from year to year [1]. Not only cases between patients and health workers, with hospital administrative staff it also often occurs. For example, the rejection of patients to seek treatment at the hospital, such as the case of many poor patients using BPJS getting rejected by the hospital. The case of a number of BPJS patients in dr. Harjono Ponorogo Regional Public Hospital who got rejected, with reason according to central BPJS policy [2]. It is such dilemma for hospitals, upholding human's honor and dignity, easing the people's access to health services; providing protection for the patient safety, the people, the hospital environment and human resources at the hospital; and improving the quality and maintain the hospital service standards [3].

Seeing this, many medical malpractice cases both in the civil dispute or criminal law must be properly handled to increase public trust [4]. This should need attention that not all of these reports bring benefits to the community, even on the contrary. For example, the news about malpractice, and lawsuits to both the hospital or criminalization of the health provider, will indirectly make people lose trust in the hospital and its personnel. Even though the hospital is a very important institution and it is needed by the people on one hand [5].

But on the other hand, many patients and patients' families treat nurses, midwives and doctors inhumanely. Several cases that have been collected by the author, based on interviews and direct observations in several hospitals in Ponorogo and outside Ponorogo, such as in Dr. Sardjono Ponorogo Hospital, Aisyah Hospital, and Darmayu Ponorogo Hospital include the cases where there are nurses who got yelled at by the patient's family, midwives who got harsh words from their patients, and some doctors who were also treated unpleasantly by the patient and the patient's family [5]. There was a midwife colleague in Pontianak who had also been treated unpleasantly by the patient and the patient's family at the Cepu hospital in Central Java there were also unpleasant things that were received by the hospital's medical staff as well as the administrative staff of these hospitals. Yet, they consider it as a risk of work that must be accepted, without complaining, without also returning the insults from patients or their families. From this arises the questions: (1) How is the Constitution related to Hospital in providing legal protection to hospitals, 
health workers, toward both civil and criminal malpractice from patients or their families? (2) What is the effort to improve legal protection for hospitals so that they are still able to provide good services and still gain public trust?

\section{CONCEPTS OF HOSPITAL'S HEALTH SERVICES IN STATUTORY REGULATIONS IN INDONESIA}

General Provision of Constitution No. 36 of 2009 explained that: "Health Effort is every activity and/or series of activities carried out in a coherent, integrated, and continuous manner to maintain and improve the degree of public health in the form of disease prevention, health improvement, diseases treatment, and health recovery by the government and/or the people". Then in Article 57 of the Constitution No. 36 of 2009 concerning Health explained that:

a. Everyone has the right to confidential personal health conditions that have been revealed to the health service provider;

b. Provisions concerning the right to confidential personal health conditions as referred to in paragraph (1) do not apply in terms of: The Order of Constitution, The Order of Court, the relevant permits, the interest of the people; or the interest of the person.

Whereas the definition of hospital in consideration to point b of the Constitution No. 44 of 2009 concerning Hospital is a health service institution for the people with its own characteristics which is influenced by health science development, technology advancement and the people's socio-economic life which must be able to improve the better-quality services and be affordable for the people in order to realize the highest degree of health. In Article 1 number 1 the general provision, it is also emphasized that a Hospital is a health service institution that conducts complete individual health services which provide inpatient, outpatient and emergency services.

In addition to the two Constitutions, there are still many Constitutions that regulate health services, namely the Constitution No. 29 of 2004 concerning Medical Practices, and this can even be related to the Constitution No. 8 of 1999 concerning Consumer Protection, the Constitution No. 25 of 2009 concerning Public Services, the Constitution No. 11 of 2009 concerning Social Welfare (which replaces the Constitution No. 6 of 1974 concerning Basic Provisions for Social Welfare), the Constitution No. 11 of 2005 concerning Ratification of the International Covenant on Economic, Social And Cultural Rights (EKOSOB), the Constitution No. 11 of 2008 concerning Electronic Information and Transactions, the Constitution No. 14 of 2008 concerning Openness of Public Information, and the Constitution No. 432009 concerning Records Management. However, due to the many regulations relating to this, it often results in a collision between one regulation and another, which then leads to the ineffective implementation of these regulations.

Health workers (Doctors, Midwives and Nurses) with their scientific instruments have distinctive characteristics. This distinctiveness can be seen from the justification given by the law that they are allowed to carry out medical actions toward human body in an effort to maintain and improve health status [7]. Medical actions toward human body that are not carried out by doctors or dentists can be classified as criminal acts [11].

Decreased public trust in medical personnel (particularly doctors), the rise of lawsuits filed by the society today is often associated to the failure of healing efforts made by doctors. On the other hand, the lack of understanding of the medical community (doctors, nurses, and hospitals) about the legal aspects of their profession is also a cause of medical disputes. This can be prevented if medical community (and also society) understand the limitations of their respective rights and responsibilities when providing or obtaining medical services [12].

While in Article 31 of Hospital Constitution, stated that the patient obligations are as follows:

a. Each patient has an obligation to the hospital for the services they obtain.

b. Further provisions regarding patient obligations are regulated by Ministerial Regulation.

Therefore, to improve all good health services, each hospital is required to have an effective, efficient, and accountable organization. Hospital organization consists of at least the Head of the Hospital or Hospital Director, elements of medical services, elements of nursing, elements of medical supports, medical committees, internal examination units, and general administration and finance. The Hospital Head has to be a medical person who meets the requirements in ability and expertise in hospital field. Structural workers who occupy positions as leaders have to be Indonesian citizens. Hospital owners is not allowed to be head of hospital [8].

\section{APPLICATION OF LEGAL REGULATIONS IN PROTECTING HOSPITALS, PROVIDING HEALTH SERVICES FOR CASES WITH PATIENTS AND THEIR FAMILY}

Health services transaction between hospital and patient is considered as an agreement. In civil cases between hospital and the patients, Indonesia as a state of law has treaty legal provisions which may be used by both parties to resolve medical disputes both litigation and non-litigation.

In the opinion of Achmad Sanusi, mentioning this agreement as a source of law because the law (Article 1338 of the Civil Code) calls it a source of law [11]. Conversely, if the laws and agreement are reviewed from the engagement law, according to Subekti, they are both referred to as the source of engagement [12]. The reference of laws as a source of engagement law in addition to the agreement, in line with the characteristics of the continental system which considers the law is a constitution. J. Satrio, citing Pitlo's opinion, criticized the reference of the said law, as it is considered more appropriate to address law has broader scope compared to the constitution [13].

Agreement law is a part of a private law, which historically and sociologically based on three different legal system, which includes Western law (Civil Code), customary law, 
and Islamic law which then resulted to the birth of agreement law as regulated in Book III of the Civil Code, customary law, and treaty law Islam [12]. Agreement theory in this study is used to examine how medical transactions occur in hospitals, from administration to patient transactions with doctors.

The agreement regulated in Book III of the Civil Code, in civil perspective is known as an engagement [13]. Article 1320 Civil Code regulates the terms of the legality of the agreement, including, first, the presence of both parties. The purpose of the term agreement is that both parties who make the agreement share the same understanding on the main points in the contract. The said agreement is a sense of sincerity or mutual give and take or voluntary between the parties involved in the agreement. The agreement is considered inexistent if the contract is made under coercion, fraud or oversight. Second, the ability to commit legal actions. The principle of competency in legal actions is an adult with healthy mind. Third, the existence of objects or other particular matters. The said particular matters refer to the objects regulated by the contract have to be clear, for it at least to be determined. Therefore, it shall not be vague. This is important to provide guarantee or certainty to the parties and to prevent the emergence of fictitious contracts. Fourth, the existence of halal clauses, whereas for the implementation of the agreement itself has to be carried out in good faith in accordance with the provisions of articles 1338 and 1339 of the Civil Code.

Article 1338 of the Civil Code (BW/burgerlijk wetboek voor Indonesie) stipulates that "each agreement made legally applies as law to those who make it". Article 1338 of the Civil Code (BW), which implies the existence of 3 (three) principles which should be in the agreement: First, regarding the occurrence of the agreement. The principle of consensualism, which according to $\mathrm{BW}$, the agreement is considered valid only if there has been an agreement of the will between both parties (consensus, consensualism). Second, regarding the consequence of the agreement, which states that the agreement has binding power between both parties. This principle is affirmed in the Article 1338 paragraph $1 \mathrm{BW}$ which confirms that the agreement was made legally between the parties, role as a law for the parties involved in the said agreement. Third, regarding the content of the agreement is completely submitted to the parties (contractsvrijheid or partijautonomie) concerned. In other words, as long as the agreement does no oppose the applicable law, decency, binding public interest and order, then the agreement is valid. Article 1365 states that each act which violates law and brings harm to others requires the person responsible to compensate for the loss as the consequence of their wrongdoing [14].

The basis of the legal relationship between patients, doctors and hospitals includes mutual agreement to commit oneself in carrying out health services. Because of the said agreement, another agreement arises which carries the rights and obligations or is called an achievement for each party. The occurrence of unlawful acts in medical agreements or transactions where on party does not carry out their obligations either in whole or in part, whether intentionally or unintentionally, is also referred to as breach of contract. Because of the said issue, a medical dispute emerges. Medical dispute issues between hospitals, doctors, patients and their families often occur in Indonesia, such as patients or families of patients who do not pay hospital bills, hospital administrations miscalculation for the costs incurred by patients or their families, doctors who misread the diagnosis of the patient's illness, which results in higher fees charged to patients, and so forth.

Medical disputes are disputes which arise from mistakes or negligence in medical practice. Broadly, medical disputes may arise from the risks of violations/provisions in health care, such as issues with the cost of care, forced discharged patients, problems with inter-profession relations, to those at risk such as malpractice. To provide comprehensive legal protection, especially for hospitals, the medical dispute resolution is considered as the last choice. The decent choice of medical might be beneficiary for hospital as it may help them to remain trusted by the community. in several laws and regulations, it is known that the rights of the hospital include: Obtain rewards for services, Sue the party who causes any loss, Obtain legal protection in carrying out health services, Undergo the process of resolving disputes outside the court (negotiation mediation) beforehand in the case of health workers suspected of negligence in carrying out their profession, Promote health services in hospital according to statutory provisions, Obtain tax incentives for Public Hospitals and Hospitals which are designated as teaching hospitals.

\section{CONCLUSION}

Indonesian laws and regulations, the relationship between medical personnel, hospitals and patients is regulated in several laws. Law No.44 of 2009 concerning Hospitals; Act No.23 of 1992 and Act No.36 of 2009 concerning Health; Law No.29 of 2004 concerning Medical Practices; Law No.8 of 1999 concerning Consumer Protection. In addition, this relationship is also related to the Criminal Code, Criminal Procedure Code, and Law No.5 Year 1986 jo Law No.9 Year 2004 jo Law No.51 Year 2009 State Administrative Court. The many rules should be able to provide legal protection for hospitals in particular, for health workers in it and patients.

The need for each party involved to understand their rights well while carrying out their obligations properly as well. The process of resolving a medical case does not always have to go to court, the law has provided the best alternative settlement in handling medical cases in the civil, administrative and criminal domains. Mediation in handling medical cases is very helpful for hospitals and health workers to be able to maintain and improve the quality of their services, but also can increase public trust, because the mediation is closed, fast and provides the best win-win solution for the parties.

\section{REFERENCES}

[1] Renggo Purnomo, peranan tenaga medis perawat dalam meningkatkan kesehatan masyarakat di RSUD aji batara agung dewa sakti kecamatan samboja kabupaten kutai kartanegara, jurnal administrasi Vol 1 no 32013 , hlm 2 
[2] Noor M Aziz 2010 Laporan Penelitian Hukum Tentang Hubungan Tenaga Medik, Rumah Sakit Dan Pasien, (Jakarta, Kementerian Hukum dan HAM) p 5

[3] m.jppn.com/news/sejumlah-pasien-peserta-BPJSkesehatan-ditolak-rs, Monday 06 August 2018.

[4] Article 3 paragraph (1) (2) and (3) Constitution No. 44 of 2009 concerning Hospital.

[5] Ngadiyono, Endri Astuti, Istirakhah, Srie Rejeki, Yahya Renaningrum, Model Pelayanan Kesehatan ditinjau dari Aspek Kualitas, Manajemen dan Sumber Daya Kesehatan di RSUP dr. Kariadi Semarang 2018, Jurnal Kebidanan, e-ISSN 2621-2870, p-ISSN 20897669 hal 87

[6] Rospita A.Siregar, Hubungan Perawat Dan Pasien: Implementasi Standar Keselamatan Pasien, Jurnal Hukum Tora, Vol. 2 No. 1, April 2016, hlm 298

[7] Wila Chandrawila, 2001 Hukum Kedokteran (Bandung, Mandar Maju) p 35

[8] Noor M Aziz 2014 Laporan Penelitian Hukum Tentang Hubungan Tenaga Medik (Jakarta, Media Tama) p 6

[9] Sumali 2003 Reduksi Kekuasaan Esekutif di Bidang Peraturan Pengganti Undang-Undang (PERPU)

(Malang, UMM) p 11

[10] Franz Magnis Suseno 1993 Etika Politik: Prinsip Moral Dasar Kenegaraan Modern (Jakarta, Gramedia) p 298-301

[11] Achmad Sanusi 1984 Pengantar Ilmu Hukum dan Pengantar Tata Hukum Indonesia (Bandung: Tarsito) p 70

[12] Subekti 2005 Pokok-Pokok Hukum Perdata (Jakarta, Intermasa) p 123

[13] J. Satrio 2000 Hukum Perikatan, Perikatan yang Lahir dari Perjanji, (Bandung: Citra Aditya Bhakti) p 4

[14] Abdul Ghofur Anshori 2006 Pokok-pokok Hukum Perjanjian Islam di Indonesia (Yogyakarta, Citra Media) p 157 